\title{
Literary Indebtedness: Selected English and Kurdish Texts
}

\author{
Ibrahim A. Murad \\ Department of English, College of Education, University of Garmian
}

\begin{abstract}
English literature has been and still is one of the major influences upon world literature due to the overwhelming power of the English language all over the world. Most of the world literature, therefore, is said to be indebted to that huge body of literature. The Kurdish literature and particularly its poetry is not an exception in this respect. Due to a number of facts and states of de facto, a number of Kurdish poets are indebted in one way or another to English poetry in general and specific poets in particular.

The paper is an attempt to show the above interrelationship through a study of selected texts by English and Kurdish poets and writers from different ages. The study chose Richard Lovelace (1818- 1658), William Wordsworth (1770 -1850), and Percy Bysshe Shelley (17971851), and Oscar Wilde (1854-1900) to represent the English poetry on the one hand and Abdulla Goran (1904- 1962) to represent the Kurdish poetry on the other hand. It came up with a number of conclusions the most obvious one of which is the fact that the Kurdish poet adopted and adapted cleverly and artistically the English texts to serve his specifics purposes.
\end{abstract}

\section{Comparative Literature}

\subsection{Definitions}

An attempt to provide a clear-cut definition for this field of knowledge is as hard and confusing as that of trying to define poetry; and the writers and critics are to blame for it. Critics are divided at least into two groups in this respect as some of them follow the principles of "French School" while others became allies to the "American School". So, defining it as "the study of literature beyond the confines of one particular country, and the study of the relationships between literature on the one hand and other areas of knowledge and belief" (Remak, qtd in Stalknecht and Frenz: 1) is quite preliminary and inadequate and raises significant questions and wonders like these: What about different literary works within one country? Is a comparative study within one literary genre impossible or unacceptable? It is for this reason, no doubt, that other critics tried their hands with attempts to illuminate the concept and term in more specific and to-the-point ideas. In this respect, S. S. Prawer writes: "Comparative literature implies a study of literature which uses comparison as its main instrument" (2). This one seems more flexible, comprehensive, and even more to-point since the term itself shows that clearly. Therefore, it is better to call it a field of study than a body of literature, as it encompasses- in many cases- at least two different literatures than a literature (italics mine). Studying two different texts within the sphere of comparison is beneficial for both texts and hence for both literatures if the texts belong to different literatures. This study 
helps the readers and critics to appreciate the studied texts better and more comprehensively. A poem by Samuel Taylor Coleridge (1772 -1834) for instance is appreciated better when compared to another poem by one of the Romantic poets on the one hand, and a poem or poems by other poets from outside the English language and literature at all on the other hand. Some critics tend to call this "general literature" in order to differentiate it from comparative literature; and this implies that comparative literature should not exceed linguistic and cultural boundaries. This, if followed, constrains the freedom that critics, writers and men of letters wish eagerly to follow, and even invented a separate nomenclature for it, i.e. world literature. It is certainly for this reason that Prawer presents a more comprehensive definition for the young literary branch:

An examination of literary texts (including works of literary theory and criticism) in more than one language, through an investigation of contrast, analogy, provenance; or a study of literary relations and communications between two or more groups that speak different languages (8).

This last definition paves the way for a better freedom in dealing with multiple literatures through the lens of comparisons and contrasts. The American school of comparative literature follows this principles; that's why it is used and followed by most critics and writers in this field of study.

\subsection{Influe nce and Indebtedness}

These two concepts go hand in hand with any comparative study, but they are not so safe and sound since contradictory ideas are put forward for each one of them. Some critics reject both concepts altogether and restrict them to the personality of the authors, and this deprives their works from any idea that link them to indebtedness or influence. Rene Wellek (19031995) for instance is one of them. He almost acknowledges influence but turns indebtedness down:

The whole conception of a 'cause' in literary study is singularly uncritical; nobody has ever been able to show that a work of art was 'caused' by another work of art, even though parallels and similarities can be accumulated. A later work of art may not have been possible without a preceding one, but it cannot have been caused by it (Qtd in Prawer: 51).

But the quotation itself draws attention to the significance of the two concepts since Wellek acknowledges the fact that in two literary works that are studied comparatively; the later one is heavily indebted to the earlier work and influenced by it; otherwise it was not 'possible' for it to appear at all. Furthermore, some works of art seem to be interrelated just through analogy not any other way. In such cases then, Wellek's idea quoted above deviates from the target and both works may have been born without that one-side influence he stresses in it. Studying such works comparatively owes much to the American school of comparative literature that, unlike its French counterpart, pushes behind the idea of interrelationship in such studies. It also widens the scope of this young branch of literature.

Although it appears to some readers and sometimes critics and writers that a work of art loses much of its originality and significance if it was influenced by or indebted to another work; yet the reality does not show it that way. Originality, as Shaw stresses "should not be understood in terms of innovation. Many great authors have not been ashamed of admitting their indebtedness to others. They seemed to have felt that originality consists, not exclusively 
or even primarily in innovations in materials or of style and manner, but in the genuineness and effectiveness of the artistic moving power of the creative work" (Qtd in Stalknecht and Frenz: 85- 6).

Influence and indebtedness, furthermore, could be strongly connected to translation especially if they happened across national and cultural boundaries; and this supports Shaw's beliefs quoted above since translation is in itself an art, a very complex one as well. In most of these cases the influenced writer adapts the original text artistically for his specific purpose and keeps the originality that readers and critics alike expect.

Another point in this respect deserves attention and interest. Influence could well happen across literary genres, i.e. a specific literary genre by a writer could be said to have been influenced by a different genre by the influencing writer. Oscar Wilde's The Nightingale and The Rose and Abdulla Goran's "Bloody Flower" that will be analyzed in this paper, make a clear example for this trend. Needless to stress that influences could happen among literary works of widely different times and ages not only within a limited period as it may occur to the mind from the first glance at the idea.

One last point concerning these two influential concepts is that in most of the cases the influence works upon those writers who start writing within a new literary movement or age. Here, the writer may feel that within the new literary environment he/she is in need for new a mode, style, theme, or even form to explain what is intended and the scope of his/her ideas and thoughts may not suffice to do; therefore outer support as far as ideas, images, allusions, or even styles are concerned, are urgently needed. The best examples for this would be the Kurdish poet under study in this paper.

\section{Compe tition on Nature}

The Kurdish teacher, journalist, and poet Abdulla Goran is mostly regarded as the father of the Romantic and new Kurdish poetry, though not without much controversy. Along with this, he was widely familiar with the Arabic, Turkish, and Persian poetries; and his familiarity with the English poetry, which is the center of interest in this paper, played a good role in the development of his romantic poems. One of the evidences for his familiarity with the English language may have been through media as Dr. Ma'arouf Khaznadar mentions: "During the second world war, he worked from September 1943 till the end of 1944 along with Ramzi Qzzaz and Rafeeq Chalak in the East Radio near the city of Jafa in Palestine. This radio station was established by Britain for launching military propaganda at Hitler's Germany" (608). This opportunity, away from literature and poetry as it was, should have left a sense of relatedness towards the English poetry especially that the man was an eager lover of poetry in the neighboring languages and the English poetry with its rich fame and popularity should have drawn him itsward greatly. Goran has become familiar with the English and European poetry and literature even earlier as he himself stresses:

We should not forget that from the beginning and due to the English literature, I followed the art for art's theory and used to read the literary products that followed it like those of John Keats and Oscar Wilde. But after 1935 I was encouraged by the progressive movement in the Arabic literature to look for samples of a progressive literature (Qtd in Abdul-Wahid: 215-16). This speech proves that the poet was familiar with the English poetry even before working in the British radio mentioned above. 
The result and outcome of this influence was great and interesting, exemplified in a number of beautiful nature poems. One of such poems is actually a ten-part poem entitled "Picnic to Hawraman" in one part of which he follows a new day from the first glimpse until the sun shines and covers everywhere in the village. The poem follows a strict time chronology starting from the very beginning of the new day: " Alla is great, the clerk declares / 'tis midst dark and night early morn" (Mulla Kareem: 131). ((All citations of Goran's poetry will be from this source and therefore only line numbers will be parenthetically mentioned))).

Most of the references mentioned above about the poet's life and interest show that he was influenced in this poem by an English Romantic poet; yet the content of the poem pushes further towards William Wordsworth (1770-1850) and especially his "Lines Written in March". The poem however shows the different strategies followed by the two poets in their respective and mostly similar poems. Wordsworth's poem starts abruptly:

The cock is crowing,

The stream is flowing,

The small birds twitter,

The lake doth glitter,

(www.english-for-students.com).

$(((($ Extracts in the following pages are taken from the same source; therefore, only the number of the lines will be mentioned)).

Before any notes about the extract and the poem in general, some few words are necessary to be mentioned concerning Wordsworth's beliefs about the concept of nature .Regarded as the father of the Romantic Movement, he toppled down some early concepts about the subject and language of poetry and its technical aspects in his famous preface to the third edition of Lyrical Ballads (1802). The preface as one critic remarks, "elevated the humble life and the plain style, which in earlier theory were appropriate only for the pastoral, the genre at the bottom of the traditional hierarchy, into the principal subject and medium for poetry in general" (Greenblatt, D, 17). The 'earlier theory' above is no more than the traditional assumption of the principle of hierarchy for poetic genres on top of which should come the epic. In that tradition the pastoral and lyric occupy just the two last places in the hierarchy line. And so, according to that tradition, Wordsworth's poem occupies the last position in that hierarchy line.

Another interesting point in the extract and the poem as a whole is its simple everyday language that is the language of a man speaking to men. It is the language of a pastoral poem with all its associations. The extract shows clearly how far Goran was influenced by this tradition and this particular poem. The first moment of a new day was declared in the first line of the poem through the usual symbol of a new day in the countryside and village life, i.e. the crowing of the cock. The only and sole difference in the initial step in both poems is related to the differences between the two cultures. In the Islamic world, the symptom of a new day is the call for prayer, although crowing of a cock is still a parallel symbol. 
The Kurdish poem follows its logical and chronological strategy since the poet is eager not to miss any moment in the series of the beauties that are associated with such a time in the early morning:

The tardy moon of night's travel

Got yellow for fear of partridge's song,

Eventime's star like hope's drops

Waned falling into cliff's snow.

(II. 3-6).

The path is quite numerical and telling. With the first glimpses of a new day, the moon's light starts waning and the personified moon is horrified of the sound of one of the most beautiful wild birds of the mountainous areas and lands, i.e. partridge. Not only the moon; rather stars are prone to leave and quit; nay, they fall down and sink into the snowy cliffs of the mountain.

The extract and in reality the whole poem meets whatever requirements a pastoral poem needs to be recognized as such. It also hints at a feeling of nostalgia for the past which seems to be lost now. Goran's lines, here, go in harmony with what is beautifully set by J. A. Cudden about the theme and purpose of a pastoral poem nowadays:

The dominating idea and theme of most pastoral is the search for the simple life away from the court and town, away from corruption, war, strife, the love of gain, away from getting and spending'. In a way it reveals a yearning for a lost innocence, for a pre- Fall paradisal life in which man existed in a harmony with nature (647).

The poetic images show how serene was the poet's mind while imagining the situation; the personified night forms a group of travellers and the lazy travellers, i.e. the moon and the stars pay dearly for their 'crime' of being late.

The analogy with Wordsworth's poem is beyond doubt; yet it deserves a great deal of attention and notice. The March poem resumes movement and progress:

The green field sleeps in the sun;

The oldest and youngest

Are at work with the strongest;

The cattle are grazing,

Their heads never raising;

(II. 5-9).

This 'overflow of powerful feeling' is no more than an 'emotion recollected in tranquility'; what an emotion! The personified field appears as if it is a parallel image to the tardy moon; and the two poets follow a similar thread of thought and imagination; yet the influenced poetthough heavily indebted to the influential Wordsworth- seems to track a stricter chronological path. With him, time passes step by step in a cinematic view without any overlaps. While Wordsworth's extract dismisses some phases and the poet's imagination hurdles forward steps ahead. From the early glimpses of the new day of the earlier extract, the reader stumbles against a sudden jump in which he/she reaches the moments when the sun spreads its strong rays and warmth over the natural scenery.

The simple everyday language of the extract and the poem- the language of man speaking to men- does not belittle the clear message of the poet about nature as a real source of life and 
originality. A new day is no more than a new chance for man in his attempts for coordination with nature- the two active elements set by God for survival and continuity of the universe.

For the Kurdish poet, another symptom for a new day is necessary before it becomes quite clear and the sun can rise:

On the route of the mountain's other side cattle bells ring,

From hunters' cache bullet sound coming.

Anon it's all bright,

Nature shows a whole magic right.

(II. 7-10).

This extracts shows clearly Goran's winning over Wordsworth as far as punctuality is concerned. While Wordsworth's cattle is already grazing; with Goran, they are still on route to pasture, that is why the sound of their bells could be heard from far. The hunter's business so far illustrates the fact that a real new working day is still ahead; since a new day with the sun's shining delineates the end of the hunters' mission and hope. It is just after these developments that a real new day with its golden brightness comes in; and only then, the viewer- the speaker in this case- can see how magical and charming the nature of his country and landscape is!

Wordsworth's concluding lines in the poem seem as if he was in a hurry to end the first winter and start a new rebirth and regeneration, exemplified by the forthcoming spring:

There's joy in the mountains;

There's life in the fountains;

Small clouds are sailing,

Blue sky prevailing;

The winter is over and gone.

(II. 16- 20).

In the previous extract, Wordsworth seems to have concluded his descriptive rove over the first minutes and hours of a new countryside spring day; that is the reason why he maneuvers around general features of the departing winter to prepare his readers psychologically for a new paradisal nature. The joy of the mountains and life in the fountains are closely related to a warmly awaited upheaval since the source of those features is rain which foreshadows rebirth and renewal.

Since the Kurdish poet is strict in the chronological development of time in his poem; this part concludes with two attention-drawing couplets where more than one natural element is involved:

On the stream, ducks and geese

Are awaiting the sun to raise its eye;

Yet until it's invited by forenoon

Sun's light will not hit the village.

(II. 13-16).

Beautifully set, ducks and geese and other birds start daily activities early in the morning and so they are 'awaiting' the rising of the sun which will be like a bell-ringing for a new rural day and practice. The sun however, is also waiting and it cannot send its first glimpses to the villagers and the 'awaiting' birds since the mountains around the villages prevent the arrival of the awaited rays until forenoon- minutes and even hours after the rising of the sun. 
Here, the interesting images decorate the poem in the same way that the different elements of nature like the village, ducks, geese, and the mountains decorate the natural scenery in it. It also tells the reader that this part is limited to just few minutes and hours of a new day and that the poem promises more beautiful scenes and images to come in the following minutes and hours. Thus Goran's poem-in this part and the others as well- seem to be more coherent and consistent than Wordsworth's "Lines".

In some cases, the Kurdish poet mentioned that he wrote certain poems under the influence of other poets, especially English Romantic poets. One clear example is "To a Nightingale" at the footnote of which he writes: "' To A Skylark' which is a poem by the famous English poet Percy Bysshe Shelley (1792- 1822), is the source of the inspiration of this poem" (Mulla Kareem: 103)

Still in this respect, Goran seems to follow all the principles and regulations of the comparative studies that were set and explained by the pioneers of this young branch of literature. It seems that he got and received the idea of a short story by Oscar Wilde (18541900) entitled "The Nightingale and the Rose" to compose a short dramatic poem entitled "Bloody Flower". (There is no reference or footnote to the poem to confirm this point). The allegation is the researcher's and he concluded it from the content of both works and the Kurdish poet's speeches during his lifetime where he stresses that he had read English texts firsthand. In this respect, he even mentions Oscar Wilde by name as it is mentioned earlier in this paper.

Wilde's work which takes the form of a fairy tale starts with a normal case of a love relation between a poor student and a well-to-do girl; but the writer weaves an attention-drawing conflict around it. A ball will be given by a prince and the couple is invited, yet the girl has a strange condition to participate and dance with her lover:

"She said that she would dance with me if I brought her red roses,' cried the young Student; 'but in all my garden there is no red rose. 'No red rose in all my garden!' he cried, and his beautiful eyes filled with tears. 'Ah, on what little things does happiness depend! I have read all that the wise men have written, and all the secrets of philosophy are mine, yet for want of a red rose is my life made wretched.' (qtd in Heward: 26). A nightingale overhears the student's dilemma as he murmurs it to himself and decides to help him. It goes to a rose tree that is ready to give away one red flower on the condition that : "You must sing to me with your breast against a thorn. All night long you must sing to me, and the thorn must pierce your heart, and your life-blood must flow into my veins, and become mine" (Ibid).

The lover gets a red rose but, shockingly, the girl turns it down: 'I am afraid it will not go with my dress,' she answered; 'and, besides, the Chamberlain's nephew has sent me some real jewels, and everybody knows that jewels cost far more than flowers (Ibid).

This interesting fairy tale along with its moral lessons and themes of love, sacrifice, selfishness, materialism, intellectualism, and emotion is adopted and adapted cleverly by the Kurdish poet Abdulla Goran in his 29- line dramatic poem "Bloody Flower". The poem starts with the lover's invitation for his beloved to a dance:

Look there, wedding, dancing

Listen! Flute, drum, dulcimer,

Please hurry up let's join 
Dance and enjoy our love.

(Mulla Kareem: 16).

(The other quotes will be made from the same source; therefore, only the number of lines will be written).

The adaptation starts from the very beginning and the occasion of the dance- unlike that in Wilde's work- is a public one and public people participate in it. The invitation is pure and naïve which shows the simplicity and ordinariness of its source. As a starting point, the two works go along in an analogous route and the two invitations do not show any critical situation or danger ahead; but here again, the conflict starts early: "With no lots of flower, yellow and red / Will not come to wedding nor dance" (II. 7-8).

In his conflict, Goran adapts Wilde's conflict and adds to it; thus making it suite the norms and customs of his society. The color yellow is preferred in such happy occasions along with red, and the poet is well aware of this fact and adapts the conflict to meet that necessity. In the development of the conflict as well, he adapts the original conflict. It is autumn and flowers are beyond reach; but the girl proposes to her lover to go to the Agha's garden where such flowers are available. The leftist background of the poet may have pushed this idea of the Agha's garden ahead, and this foreshadows more complications in the original conflict:" I searched Agha's garden up and down / I got and brought yellow, but the red no / I wonder whether you come to the wedding and dance or no? (II. 22-24).

The conflict-unlike Wilde's one- goes on unsolved and declining the invitation is most expected. The poet, cleverly, reserves the climax for the last few lines and keeps the reader waiting eagerly for the final solution for the problem and denouement for the story of the poem. Although Wilde does the same thing in his short story; yet the strategy, here, is different and draws even further attention and causes more puzzlement. Upon the beloved's rejection of the invitation, the lover tears up his shirt, and shows her his injured chest: "Woe is me! Enemy's weapon hit you? / Lie down on my lap, / To weep for a heart I lost for a rose" II. 27-29).

The denouement seems most unexpected since- Wilde's story and the autumn season considered- the reader expects a failure from the part of the lover in fulfilling the girl's demand and condition. Another point strengthens this puzzlement; the writer does not follow Wilde's example in creating a fairy tale in the story of his poem; thus no supernatural elements are expected.

Both Goran and Wilde's stories share some common themes like love, nature, and sacrifice; but the Kurdish poet's adaptation of the English story includes this element as well. Whereas in Wilde's story the girl is found out selfish, materialist and not true to her love; the girl in Goran's poem- though she shows some stubbornness and strictness- is a real love. Upon discovering the range of the sacrifice her lover did for her sake, she comes to herself and discloses how much she is sorry for her earlier stubbornness and difficult condition and how far she is affected by her lover's fatal injury.

The poet chooses the couple from ordinary people; thus giving his story a strong range of reality and dependability. Again, the poet's ordinary lifestyle and leftist background play roles.

The girl in Wilde's story does not pay any heed to the fact that getting a red rose in such a time of the year is difficult and problematic; neither has she even asked how the rose was 
found. She carelessly and neglectfully just rejects it on false justification though she mentions the real reason for her rejection, 'everybody knows that jewels cost far more than flowers'. Another reason for this may be the superiority of the girl as a professor's daughter, and inferiority of the boy as: "I tell you what, you are very rude; and, after all, who are you? Only a Student. Why, I don't believe you have even got silver buckles to your shoes as the Chamberlain's nephew has" ( Qtd in Heward: 32 ).

Taking into consideration the political situation of the Kurds at the time of the poet, political and revolutionary poems by Goran do not come as surprise and in this respect as well he made use of and got benefit from English poetry. In a poem composed of ten four-line stanzas and a concluding couplet and entitled "Martyr" this indebtedness becomes obvious. The poem was composed on the occasion of a demonstration launched in Sulaimani city, Iraqi Kurdistan, in 1930 where the Kurdish young demonstrators shouted against the kingdom authorities of the Iraqi UK supported government and asked freedom for their people and country.

The speaker in the poem is one of the demonstrators who is shot dead by the military forces. In the last two stanzas, the speaker addresses a nightingale that witnessed the massacre and sends a message:

$$
\begin{aligned}
& \text { Oh, Sara* nightingale! ... though 'tis atumen, } \\
& \text { my blood will breed you flowers, then sing for me, }
\end{aligned}
$$

Tell my first-night bride if she came on my corpse,

Not to say why he killed himself and did not live for me?

Duty was to sacrifice for a such land that

In the lap of the mountains bred you for me.

(Abdul-Kareem: 267).

* Sara is square in the middle of Sulaimani.

The scenario is chilling and the mixed feeling towards two contradictory situations is telling. The speaker is a newly wedded young patriotic person who was with his bride just one night before the moment of his martyrdom. The poet cunningly supposes that due to the atrocity of the military attack, nobody is left alive so that the speaker (who is supposedly dead) can send a message through him to his bride; therefore, he sends news to her via a nightingale that witnessed his death. The sacrifice was not a duty just because his land deserves; rather because that land is the mother that brought his bride up. In this way, the poet creates a strong connection between the two seemingly contradictory loves: love of country that necessitates sacrifice and consequently death and love of a bride that demands living and enjoying life.

These ideas are borrowed from a short lyric by the English seventeenth century poet Richard Lovelace (1618- 1658) entitled "To Lucasta, Going to the Wars". The poem is included in his volume Lucasta (1649). The speaker, here, addresses his girlfriend directly:

Tell me not, sweet, I am unkind,

That from the nunnery

Of thy chaste breast and quiet mind,

To war and arms I fly.

(Ferguson: 473).

First of all, this lyric shows some aspects of the sensibility of the poet and the trend of the cavalier poetry of which he was a member. As one famous critic notes, it "voices the Cavalier 
attitude at its best to life and to the war. We find, here, the surviving code of chivalry and the public values of the seventeenth century country gentleman expressed with great clarity and with intellectual ingenuity and sophistication of tone" (Ford: 3: 215).

The very beginning of the short lyric does not tell only of reception and indebtedness, rather, it tells of the clever adaptation of the original lyric by the influenced poet. The poem starts at a moment when the speaker decides to leave his girlfriend and join the army as a knight. The speaker tries to convince the girlfriend that leaving her is not in vain, rather it is for a noble purpose and achievement. He is seeking honour which for him, can be won only through serving one's own country and land. The simple, yet clever diction, serves the target of the speaker minutely. Through the word 'chaste', he wants to stress that his love for her exceeds the mere sexual desire. It rises above it to the level of love of country and even religion. These ideas need to be clarified to the beloved and a kind of compromise is necessary:

Yet this inconstancy is such

As you too shall adore;

I could not love thee, dear, so much,

Loved I not honour more.

(Ibid).

The binary opposition is put forward and the speaker-lover tries to convince the beloved of loving it as well. He creates a parallel line between loving her and loving honour, and this, necessarily, can calm her down and even put her in the situation of a proud person. This concluding couplet, one feels, serves a logical and acceptable coda for the short poem.

In the Kurdish poem, some details are inserted as a kind of adaptation in order to suit the social, cultural, and political environment under which it was composed. While Lovelace just tries to convince his beloved to understand and consider his sacrifice; the speaker in Goran's poem goes steps further ahead: If God gifted you with a son; tell it "my son / Father wanted from me tears but revenge from you" (Abdul-Kareem: 267).

The speaker does not want to join any army neither to fight in it; rather he joined his revolutionary people who protested against the occupiers of their country. Even more, he expects to be shot down by the military forces of the occupiers. It is for this certain feeling of his end that he wishes to say and send his will to his newly wed wife. The patriotic feeling, here, though more tragic; yet truer to life and to the route of events that were to be expected in advance with a great rate of certainty.

The concluding lines, though tragic and bloody, promise a lot. The wife should lament the loss; yet she was commissioned with a very noble obligation to bring up and teach the newly born child to follow his father's example and continue the path he was leading. This conclusion starts at a stark contradiction to Wilde's conclusion where the young man tosses his dearly-got gift away and decides to quit love for life.

The difficult and critical situation of the poet and his people at that time (the poet was jailed more than once over his political and leftist bias), however, did not distract him from the interesting elements of nature that decorate the landscape of his homeland's countryside, as the first example in this paper illustrates. It seems that he read and was attracted to Percy Bysshe Shelley's (1797-1851) "To a Skylark" and this infatuation inspired in him the idea of a similar poem to which he gave the title "To a Nightingale". The minute analogy is obvious 
and the one different word proves the originality of Goran's poem despite its heavy indebtedness to Shelley's. The Kurdish poet was aware of the fact that the nightingale of his landscape fills the place of the skylark which is specific to very cold areas and regions. Shelley initiates "Skylark" with an interesting admiration of the bird. He even personifies it and addresses it directly through an imaginary conversation.

Hail to thee, blithe Spirit!

Bird thou never wert,

That from Heaven, or near it,

Pourest thy full heart

In profuse strains of unpremeditated art.

(Ferguson: 876).

It seems that a real incident inspired the poem as Mary Shelley, the poet's wife, in her note about the poem wrote: "while wandering among the lanes whose myrtle hedges were the bowers of the fire-flies ... we heard the caroling of the skylark which inspired one of the most beautiful of his poems' (Qtd in Hebron: 1). For Shelley, the skylark was never a bird; rather, it was one of the sources of the power of nature that created this ' unpremeditated art'. This power can consequently be attributed to God's power and His gifts to mankind since the Romantics regarded nature and its elements as symptoms of Almighty God's power.

The Kurdish alternative starts almost similarly:

O! attractive bird,

Small-beaked nightingale,

From grove to grove ye fly,

Repose somewhere as you try.

(Abdul-Kareem: 103).

It is a normal and ordinary starting-point with no reference altogether to any divine symbol or aspect. His leftist background should have played a role in this respect; and so the reader comes across a familiar inauguration; that's why the initial step in the English poem seems heavier in weight and value. Shelley tells the skylark about its pleasure and he compares human pleasure to that of the bird:

With thy clear keen joyance

Languor cannot be:

Shadow of annoyance

Never came near thee:

Thou lovest: but ne'er knew love's sad satiety.

(Ferguson: 878).

The bird is active and joyous without any disturbance which-the poet indirectly conveysis an obvious feature of man's pleasure and vitality. The skylark's love of life is exclusive since it will never reach the point of complete satisfaction, and so it is always thirsty for more. This seems ultra-natural for the poet who seems jealous of the bird's happiness and pleasure; it is for that reason he asks it for help and support:

Teach me half the gladness 
That thy brain must know,

Such harmonious madness

From my lips would flow

The world should listen then, as I am listening now.

(Ibid).

Shelley is asking the bird for the source of the pleasure that it enjoys and he is deprived of because he thinks that if he possesses such an ecstasy, he would be able to follow the bird's example and make the entire world listen to him eagerly the way he is doing towards the bird's voice now. The extract and the poem as a whole expose Shelley's desire to know the secret behind the bird's happiness and its natural inclination to sing, since man's inclination in this respect is intermitted and often polluted by shocks of sadness. The poet tries to picture the bird as an artist of nature, may be, to compare it to himself and his poetry. He wants to make it clear that his poetry (and may be this poem) as a product of human being fails to parallel the joy and pleasure expressed by the bird. But he does not reveal the reasons behind man's sadness that prevents him from providing and enjoying a pleasure like that of the skylark.

The Kurdish poem, though imitating its English counterpart, follows a strategy that well serves its purpose:

Had my inmost been pleased,

And of dungeon freed;

Around 'twere flowery

And all my life spring be.

Yet, o! woe be me,

Am a man not a bird.

Our life ever for life,

Pain and suffering.

(Abdul-Kareem: 104).

Goran wishes he were pleased and free of confinement that would enable his life to be forever spring. This means as well that his hope and desire are beyond attainment. He puts himself in the position of the symbol of humanity as a whole. The poet's social and political background again should be taken into a real consideration. The poem was composed at a time when the poet's people were suffering severely under the control of the Iraqi authorities that ill-treated the Kurds in the country.

\section{Conclusions}

As a result of the brief analys is of the different texts, the short study reached a number of conclusions about the relationship between the Kurdish and English literatures and specifically between the Kurdish poet, Abdulla Goran on one side and William Wordsworth, Percy Bysshe Shelley, Richard Lovelace, and Oscar Wilde on the other side. The most prominent conclusions are as follows:

1. The Kurdish poetry fell heavily under the influence of its English counterpart and this influence was reflected in a number of Kurdish well-known poems from different ages. 
2. The influence of the English works and poems helped the Kurdish poets and writers to come up with literary products that compete with the original texts and in some cases win over them.

3. The Kurdish indebted and influenced writers and poets sometimes referred to that fact as footnotes to their texts, while at other cases they did not make any notes; due to specific reasons or just as a matter of forgetfulness; especially that they passed critical times and faced multi-phased difficulties throughout their lives that affected even the process of publishing their works.

4. The influenced works and poems prove the fact that the Kurdish poet not only understood the English texts well, but felt and imagined the atmospheres that led to the production of those English works; that is why their works and poems draws the attentive reader back to the world of the English texts.

5. The different political, social, and cultural background of the Kurdish poems from the English texts seems to have paved the way to different concluding ideas between the Kurdish poems and the English texts.

\section{References}

1. -Abdul-Wahid, Azad. Sheikh Noori Sheikh Saleh'd Oeuvre. Vol.1. 2nd Edition. Aras Publishing Press. Erbil. Kurdistan Region. Iraq. Print

2. Cudden, J. A. Dictionary of Literary Terms \& Literary Theory. 4th Edition. U.K. : Clays Ltd, St Ives Plc. 1998. Print.

3. Ferguson, Margaret, et al. The Norton Anthology of Poetry. 5th Edition. New York: W.W. Norton \& Company. 2005. Print.

4. Ford, Boris. The New Pelican Guide to English Literature. Vol. 3. London: Penguin Books. Clays Ltd. St. Ives plc. 1990. Print.

5. Greenblatt, Stephen (ed). The Norton Anthology: English Literature. Vol. D. London: w.w.Norton \& Company. 2012. Print.

6. Hebron, Stephen. "An introduction to 'To a Skylark'". https://www.bl.uk/romantics-andVictorians. 15 May 2014. Accessed in 6-1-2019

7. Heward, Victoria (ed). Oscar Wilde's Short Stories. Barcelona:Black Cat. 2007. Print

8. Khaznadar, Ma'arouf. History of the Kurdish Literature. Vol.6. Erbil: Aras Publishing Press. Kurdistan Region. Iraq. 2010. Print.

9. Mahmoud, Fazil Majeed. Nature in the Poetry of Goran. Suleimanyia. Kurdistan: Sardam Publishing House. 2007. Print.

10. Mulla Kareem, Muhammad. Collected Poems of Goran. Baghdad: Iraqi Scientific Academy Publishing House. 1980. Print.

11. Prawer, S. S. Comparative Literary Studies: An Introduction. G. B. : Redwood Press Limited. 1973. Print.

12. Stalknecht, Newton \& Frenz, Hornz (Ed). Comparative Literature: Method and Perspective. London: Southern Illinois University Press. 1961. Print.

13. http://www.english-for-students.com/lines-written-in-march.html. Retrieved in 22-112018. 